\title{
Young People and Political (In)Activism: Why Don't Young People Vote?
}

\author{
Matt Henn and Mark Weinstein \\ Policy \& Politics, Vol 34 no 3, pp. 517-34, 2006. \\ DOI: $\underline{\text { http://dx.doi.org/10.1332/030557306777695316 }}$
}

Economic and Social Research Council award R000223598: First-Time Voters' Attitudes towards Party Politics in Britain.

\begin{abstract}
Continued experimentation with methods to make the process of voting easier signals a growing concern amongst politicians that the public is becoming increasingly disaffected from politics in Britain. However, these government initiatives may be failing to tackle the real problem- that the electorate appear to find the business of politics uninviting and irrelevant. In this article we examine the results from a nationwide survey of over 700 young people, and find that this generation, whilst supportive of these new electoral methods, are unlikely to be persuaded to turnout to vote while they continue to feel marginalised from the political process.
\end{abstract}

KEYWORDS: youth / voting / political participation / political apathy 


\section{Introduction}

The Labour Party's victory at the 2001 British General Election, winning with a majority of 167 seats, represented the greatest second-term victory of any party in British political history. Yet the outcome was anything but a ringing endorsement by the electorate for Labour and the other main political parties that were returned to Westminster. With only 59 per cent of the eligible electorate casting their vote, the election recorded the lowest voter turnout rate since 1918, representing the culmination of a recent trend in 'record' voter abstention rates in Britain. ${ }^{1}$ The apparent disconnection between citizens and the political process signalled by this led some to conclude that it represented a developing crisis of democratic politics in Britain (Harrop, 2001; Whiteley et al., 2001). In particular, only 39 per cent of 18-24 year olds voted at this 2001 election, and whilst overall turnout increased marginally to 61 per cent at the 2005 General Election contest, it fell further amongst this youth group to only 37 per cent (The Electoral Commission, 2005a).

From the late 1990s onwards there has been a steady rise in interest in young people's political behaviour. In recent years we have seen the publication of a number of important studies that explore young people's perception of formal political institutions, their trust in the system, and their attitudes towards political parties and elections. Central to many of these studies is a concern about the rise of a politically 'disengaged' youth generation that is marked by its apparent disinterest in, and lack of knowledge of, matters 'political' (Heath and Park, 1997; Park, 2000). Furthermore, these young adults are considered to have little motivation to take part in collective civic action to shape the political world around them (Jowell and Park, 1998; Pirie, and Worcester, 1998 and 2000). They are the least likely of all adults to vote or indeed to register to vote, to volunteer support for political parties, or to join such political organisations (Cole, 1997; Russell et al., 2002). Indeed, some authors have concluded that there is evidence of a "historical political 
disconnection" (Wilkinson, 1996: 242) reflected in young people's apparent "unwillingness to obey the law, to play by the rules, or to pay for the needs of others" (Mulgan and Wilkinson, 1996: 218). Whilst this level of contemporary interest is new, the central messages conveyed by such research - that young people are becoming increasingly disconnected from the political process - have not changed for quite some time. Parry et al's (1992) landmark study of political participation in Britain, the fieldwork for which was carried out between October 1984 and January 1985, came to broadly the same conclusion about young people's engagement with formal political institutions.

Such findings have been challenged in a number of recent studies which suggest that young people are interested in political matters, and $d o$ take part in differing forms of political action (Bhavnani, 1994; White et al., 2000; Henn et al., 2002; Roker and Eden, 2002; O’Toole et al., 2003; Cunningham and Lavallette, 2004; Weinstein, 2004). Research conducted by Norris (2003) indicates that young people are more likely to engage in 'cause-oriented' styles of politics (or what Pattie et al. (2003) refer to as 'micro-politics') than they are in 'formal' politicsparticipation that uses less institutionalised methods such as demonstrations, boycotts, and direct action. ${ }^{2}$ Their participation in the various anti-globalisation events that have taken place since Seattle in 1999, and their joining in of marches and demonstrations in protest against the war in Iraq are very high profile examples. Young people also take part in more localised social action activities, although they do not themselves consider these to be 'political'. Such activities include volunteering, informal community networks, neighbourliness, informal political action, awarenessraising, altruistic acts, and general campaigning (Roker and Eden 2002, p.7). 
However, despite such evidence of their engagement in political action, the central preoccupation with falling turnout rates of young people in elections persists. As a consequence, there is widespread concern amongst politicians and officials that this apparent generation of political sceptics will carry their deep aversion to the political process with them into later life, in time replacing the more civic-oriented older generations, and ultimately calling into question the legitimacy of the political system itself (See for instance, the Department of the Environment, Transport and the Regions [1998]). Most recently, in responding to the low turnout at the 2004 European Election, the President of the European Parliament, Pat Cox, warned that 'apathy is the greatest enemy' (Black, 2004). This view also remains dominant in media discourses, where the received wisdom is that declining turnout is symptomatic of citizen apathy (Johnston, 2001; Preston, 2004).

This concern about voter disengagement in Britain (particularly amongst young people) has come to the fore in recent years, largely as a consequence of the record voter abstention rate recorded at the 2001 General Election. But discontent with the British political system precedes this election, and became a visible phenomenon from the 1970s onwards with the publication of a series of key studies that uncovered a general sense of dissatisfaction with the functioning of democracy in Britain, one that was more pronounced amongst young people (Royal Commission 1973a; Marsh 1977). This picture of the general population was supplemented by two studies specifically addressing young people's attitudes towards politics and government. In comparing young Britons with their American, German and Italian counterparts, Dennis, Lindberg and McCrone (1971) paint a negative picture of young Britons' support for government and political institutions, demonstrating a generally unfavourable sense of national identity and a critical disposition towards Britain's role in the world. In a similar vein, Hart $(1978,46)$ uncovered a 'lack of basic trust or faith amongst British teenagers' in the functioning of British democracy. 
The events of the succeeding years have done little to challenge Marsh's (1977: 115) contention that in general people regard politics as 'a remote and unresponsive system run by cynical and aloof politicians'. If anything, the growing sense of remoteness and disenchantment with politics has vindicated the authors of the minority report of The Royal Commission of the Constitution (Royal Commission 1973b) who recommended urgent action to address what they perceived to be deepseated problems with the functioning of British political institutions.

\section{The Government Response}

The response of Prime Minister Blair's government to current trends has been to try to find ways in which the electorate, and young people in particular, can be 'reconnected' to the political system, and a sustainable democratic culture be embedded. A programme of constitutional change is underway that is ostensibly designed to devolve power from Westminster to the regions and localities, and in doing so to provide citizens with greater access to the centres of political power, and increased influence over the political process. These changes include a continuing commitment to reform of the House of Lords, and a method of proportional representation has been implemented for the European Assembly elections. Furthermore, mayors have been elected in London and several other cities and large towns, regional tiers of government for England have been discussed and in some cases voted upon, and the Government has established directly elected chambers in Scotland, Wales and London. ${ }^{3}$

The Government have sought to address young people's political attitudes and civic orientation through the introduction in 2002 of statutory citizenship classes in schools. This educational 
initiative is intended to educate young people in "the nature and practices of participation in democracy; the duties, responsibilities and rights of individuals as citizens; and the value to individuals and society of community activity" (Crick, 1998: 4). The orders to make citizenship a statutory subject for teaching in schools were passed by parliament in February 2000. As then Secretary of State for Education and Employment, David Blunkett commented:

\footnotetext{
"It is one of the most important steps in developing and understanding our democracy, and encouraging active citizenship that has been produced for a very long time... I hope this will engage young people in their community and in their understanding of the subject" (in Crace, 2000)
}

Finally, the Government has sought to modernise the electoral system and processes in an attempt to make the act of voting easier. In doing so, it has drawn attention to what it considers to be the central role that stimulating turnout at elections has in reinvigorating people's connection with the democratic process: "(Renewal of democracy) can only come about if there is higher participation in elections and close regular contact between a council and local people between elections" (Department of the Environment, Transport and the Regions, 1998: 38). Thus, the Representation of the People Act 2000 sanctioned the use of experiments in local elections to encourage people to register to vote, to remove perceived disincentives to vote, and to make voting easier - the latter included electronic voting, mobile polling stations, voting during different hours, on different days or over a number of days, and all-postal voting. Recent evidence suggests that the impact of these electoral initiatives is mixed; even all-postal postal voting - the method that has met with most success - is failing to make engage the electorate's appetite for voting in any significant way. ${ }^{4}$ 
Nonetheless, the Government appears to be placing significant faith in mechanistic solutions to address what it considers to be the chief issue of boosting election turnout, rather than more complex issues that may influence the way in which citizens engage with the political process. ${ }^{5}$ A key question therefore remains for both the Government and for the academic communitythat is, whether the introduction of procedural electoral mobilising devices is capable of solving an issue that may have origins that are distinct from the accessibility and convenience of voting methods. It is our contention that these origins may well be grounded in an increasing antipathy that citizens (particularly young people) have for the political system in Britain, and their aversion to political parties and professional politicians. Consequently, deploying methods to boost turnout in elections will by itself fall short of what is necessary if young people are to become genuinely engaged with the political process in Britain, and if the democratic process is to regain legitimacy in the eyes of a sceptical public.

\section{Research Design}

In order to investigate this contention, we report the findings from a survey of attainers-18 year olds eligible to vote in an election for the first time. This national sample was based on the random selection of young people from the electoral register who were mailed questionnaire surveys that included a mix of both closed and open-ended questions. We received 705 questionnaires from 3,109 sent out, resulting in a final response rate of 23 percent. The data were weighted to take account of the distribution of the British youth population across the key variables of region (and nationality), gender, social class, and ethnicity. Tests confirmed that the weighted and unweighted data were closely matched, indicating that our survey results did not 
over- or under-reflect the views of people from different socio-demographic groups. This was important as we wanted to ensure that our sample contained a broadly representative crosssection of the British youth population. However, issue saliency is an important motivating factor in all research, and with the exception of the census, all research studies involve selfselecting samples. Naturally we were faced with the possibility therefore that any such sample might contain only the most interested section of young people - that the "disinterested" would be less inclined to participate in a survey about political matters. To reduce any such effect, we offered free entry to a prize draw for all those who participated in the study.

Interestingly, when we compare the findings of our survey of 18 year old attainers with 18 year olds from the post-election 2001 British Election Study (BES), we find that our study appears to have captured a more or less identical group of "disengaged" young people. Fifty seven per cent of those reported in the BES survey claim at least "some" interest in politics, compared with 56 per cent of our sample. (It should be noted that the 18 year old sub-group from the BES numbers only 36, whilst our sample numbers in excess of 700 attainers.) Certainly we consider that our research strategy has not therefore resulted in a youth sample that is overly interested, engaged, and enthusiastic about 'politics'; as we shall see, the data reveal a sample that is highly critical of the way in which politics is organised in Britain. Nonetheless, if our sample does contain the most politically engaged of British youth, then in all likelihood the wider youth population will be even more disenchanted with politics in this country.

Our study represents the first large-scale study of its kind in Britain, as previously-published academic studies are either relatively old (e.g., Jennings, 1960; Layton-Henry, 1973), or else limited to a small number of case studies (e.g., Bhavnani, 1994; Bynner and Ashford, 1994; White et al., 2000), or based upon the analysis of relatively small sub-samples of young people 
taken from samples of the general voting-age population (e.g., Heath and Park, 1997; Park, 2000). Furthermore, such research tends to focus on the more general field of young people and politics, although typically, this does not give specific or detailed attention to party politics. It is our contention that the way in which party politics is conducted in Britain contributes significantly to the apparent disconnection between young people and the political process in Britain.

\section{Is Britain's Youth Politically 'Apathetic'?}

The survey data reveal that contrary to claims made in some quarters that they are apathetic, young people are interested in politics. When asked about politics in general, $56 \%$ of respondents replied that they had some or more interest in the topic (which compares with $13 \%$ who had none at all). Furthermore, nearly half (48\%) claimed to have been interested in the 2001 General Election that had been held the previous summer (only 17\% had no interest at all), and a majority (54\%) considered that they would discuss politics with friends and family in the future.

Young people are particularly interested in political issues. We asked an open question-“In your opinion, what is the single most important issue at the moment?"- that revealed that this youth generation embraced a wide range of concerns. That nearly all respondents completed this question (88\%), may itself be an important signifier of their interest in political issues. ${ }^{6}$ Grouping these qualitative responses thematically, the data indicate that nearly half of our sample were preoccupied with mainstream concerns about public services (health $28 \%$, education $14 \%$, transport 4\%) and traditional 'materialist' issues (economic matters 7\%, Europe 6\%, crime and 
10

law and order 6\%). A noticeable minority (13\%) prioritised 'postmaterialist' concerns about wars and militarism, solidarity with the third world, animal rights, and environmental protection. Taken together, these results seem to run counter to any view that young people are apathetic, taking little interest in political affairs.

\section{Democracy and the Electoral Process}

Not only are they interested in matters 'political', young people also appear to have faith in the democratic process, and they are generally supportive of the notion of elections - the key means open for them to formally participate in politics and influence those issues that concern them. Respondents were more likely to be satisfied (31\%) than dissatisfied (26\%) with the way democracy works in Britain (although 28\% held an ambivalent "Neither Satisfied Nor Dissatisfied" view). Furthermore, young people claim to have a general attachment to and confidence in the electoral process, with twice as many disagreeing (49\%) than agreeing (24\%) with the sceptical statement that "...most elections are just a big waste of time and money". This commitment to the democratic process is reflected somewhat in their stated intentions to vote in future electoral contests. As Table 1 demonstrates, a large majority claimed that they planned to vote at the next general election, with noticeably high numbers of respondents reporting that they intended to turnout for local and European electoral contests. ${ }^{7}$

It may appear somewhat of a paradox then that this general support for the democratic and electoral processes does not translate into high participation by the public in elections; indeed, as electoral returns show, youth voting has been on the decline in recent years. ${ }^{8}$ As has already been discussed, in recent years the government has initiated a series of constitutional and electoral reforms specifically designed to foster increased electoral participation. 


\begin{tabular}{lcc}
\hline & $\begin{array}{c}\text { Likely } \\
\%\end{array}$ & $\begin{array}{c}\text { Unlikely } \\
\%\end{array}$ \\
\hline How likely is it that you will vote in the next national election? & 67 & 16 \\
$\begin{array}{l}\text { How likely is it that you will vote in the next local council } \\
\text { election? }\end{array}$ & 47 & 32 \\
$\begin{array}{l}\text { How likely is it that you will vote in the next election for the } \\
\text { European parliament? }\end{array}$ & 37 & 38 \\
\hline
\end{tabular}

NB. Figures do not sum to 100 as they exclude those who answered with a neutral response or replied "Don’t know".

One of these reforms includes the introduction of new voting arrangements for certain types of elections. Alternatives to the first-past-the-post voting system were introduced in the UK for the 1999 European Assembly elections, and for elections to the new Scottish Parliament, the Welsh Assembly and the London Authority at the same time. The evidence suggests that the methods have had little impact in capturing the public's imagination. For instance, only $39 \%$ voted for the European Assembly elections in 2004, with 49\%, 38\% and 36\% voting respectively for the Scottish (2003), Welsh (2003) and Greater London Authority contests (2004). Our results give some insight as to why altering the electoral system has failed to stem the tide of increasing voter abstentionism in the UK - the survey indicates that the new arrangements seem to have as many detractors as they do supporters among young people. Only $26 \%$ agreed with the statement that "we should change the voting system to allow smaller parties to get a fairer share of MP's", while $29 \%$ supported the contention that "we should keep the voting system as it is to produce effective government". A similar figure (25\%) claimed that changing the current system of voting would make no difference ( $20 \%$ were left unsure). 
12

New systems of voting therefore are failing to provide the stimulus necessary to engage the public in elections and increase their propensity to vote. But what of other initiatives open to the Government? As noted earlier, another approach that the Government has taken in order to address this apparent paradox between the high levels of support for elections and deepening electoral abstentionism is to introduce new voting methods. We gauged survey participants' responses to several of these new experimental and actual voting methods by asking them whether or not they considered that they would increase their likelihood to vote in future elections. Table 2 summarises their reactions. The findings clearly indicate that for all cases, those who view the introduction of these procedural changes positively significantly outweigh the numbers of those who view them negatively. This ranges from a $30 \%$ difference on the considered method of introducing balloting arrangements in public places such as supermarkets and public libraries, to a $54 \%$ margin of difference between enthusiasts and sceptics for extending the voting period over more than one day. The results are perhaps not surprising, given that people are unlikely to report that making the voting system more flexible would reduce their propensity to vote, ${ }^{9}$ but it does nonetheless signal a general support for the new voting methods.

\section{Attitudes to the Political Process}

In order to examine the apparent contradiction between attainers' enthusiasm for the new voting arrangements and their low propensity to vote, we asked several questions designed to uncover their general orientation to the political process and to those key agents who dominate it, the political parties and professional politicians. The results indicate that the new voting methods are unlikely by themselves to halt the continuing decline in voter turnout because they fail to address the real source of young people's disconnection from the British political process - that 
this generation appear to find the whole business of politics remote, irrelevant, uninviting, and alienating.

Table 2: Proposals to Increase Voter Turnout

\begin{tabular}{|c|c|c|c|c|}
\hline $\begin{array}{l}\text { Would you be more or less likely to vote if } \\
\text { you were able to: }\end{array}$ & $\begin{array}{c}\text { More } \\
\%\end{array}$ & $\begin{array}{c}\text { Less } \\
\%\end{array}$ & $\begin{array}{c}\text { Make no } \\
\text { difference } \\
\%\end{array}$ & $\begin{array}{c}\text { Net turnout } \\
\text { change (+/-) } \\
\%\end{array}$ \\
\hline Vote in a public place such as a supermarket & 37 & 7 & 57 & +30 \\
\hline $\begin{array}{l}\text { Vote over more than } 1 \text { day (including } \\
\text { weekends) }\end{array}$ & 57 & 3 & 41 & +54 \\
\hline Polling stations were open for 24 hours & 44 & 4 & 53 & +40 \\
\hline Vote by post & 48 & 7 & 44 & +41 \\
\hline Vote by phone & 45 & 12 & 44 & +33 \\
\hline Vote via the Internet or digital TV & 50 & 11 & 39 & +41 \\
\hline Voting was compulsory & 53 & 14 & 33 & +39 \\
\hline
\end{tabular}

As Table 3 demonstrates, young people clearly have a 'civic imperative', expressing agreement with the sentiment that they would be neglecting their duty as citizens if they did not vote. Nonetheless, they qualify this by stating that they would only vote if they cared who won, signalling a caution that parties that converge are likely to alienate young people. This appears to be a major factor governing the increasing withdrawal of young people from the political process and their abstention in elections, in that they are twice as likely to agree than disagree that the main parties represented in Westminster are failing to offer voters clear policy choices in elections. Furthermore, young people consider that elections as a method of democratic participation are limited, and they are broadly sceptical that the outcomes from these contests are positive. Most respondents believe that voting fails to give rise to meaningful change in society 
14

and in the way that we are governed. Crucially, they feel that they are treated unfairly by governments and marginalised from the wider political process, with little control or influence over the decision-making process.

\section{Attitudes to the Political Parties and Politicians}

Not only do young people perceive the political process and those who govern it to be remote and inaccessible, they are also highly distrustful and critical of those who vie for control of it. Today's youth appear to hold deeply sceptical views of the mainstream political parties and elected politicians, and of the way that they conduct their activities.

Table 3: Support for Democracy and the Electoral Process

\begin{tabular}{|c|c|c|}
\hline & $\underset{\%}{\text { Agree }}$ & $\begin{array}{l}\text { Disagree } \\
\%\end{array}$ \\
\hline I would be seriously neglecting my duty as a citizen if I didn't vote. & 43 & 32 \\
\hline I would only vote in an election if I cared who won. & 47 & 30 \\
\hline $\begin{array}{l}\text { The main political parties in Britain don't offer voters real choices } \\
\text { in elections because their policies are pretty much all the same }\end{array}$ & 48 & 22 \\
\hline $\begin{array}{l}\text { Elections allow voters to express their opinions but don't really } \\
\text { change anything }\end{array}$ & 60 & 22 \\
\hline $\begin{array}{l}\text { By voting I feel as if I can/could really help to change the way that } \\
\text { Britain is governed }\end{array}$ & 28 & 44 \\
\hline The government generally treats young people fairly & 23 & 42 \\
\hline Governments don't really care what young people like me think & 39 & 26 \\
\hline $\begin{array}{l}\text { There is a big gap between what young people expect out of life and } \\
\text { what we actually get }\end{array}$ & 64 & 12 \\
\hline Young people like me have no say in what the government does & 62 & 21 \\
\hline $\begin{array}{l}\text { There aren't enough opportunities for young people like me to } \\
\text { influence political parties }\end{array}$ & 71 & 7 \\
\hline
\end{tabular}

NB. Figures exclude those who answered with a neutral response, or replied "Don't know". 
Perhaps not surprisingly, young people have a relatively low level of party identification, with only $28 \%$ claiming a loyalty with any of the political parties, compared to $59 \%$ who report that they have no such emotional ties. Other findings from the survey support the view that today's youth generation have little confidence in political parties and professional politicians. Our results tend to reinforce those from a number of other studies (Curtice, 2002; Johnson and Marshall, 2004) that show an apparent disconnection from party politics - in many cases this is very noticeable indeed. Nearly all respondents $(87 \%)$ claimed that there is often a big difference between what a party promises it will do and what it actually does when it wins an election. Only a fraction (3\%) disagreed with this statement. They are also sceptical of the motives that political parties have in courting the electorate during election campaign periods. Seven in ten $(69 \%)$ attainers claimed that political parties are more interested in winning elections than in governing afterwards, with only $13 \%$ dissenting from this view. Furthermore, attainers perceive political parties to be only interested in people's votes, rather than in their opinions (agreed 65\%, disagreed 14\%). Significantly, these political agents are condemned for the manner in which they conduct their activities. Survey respondents claimed that political parties do more to divide the country than unite it (by a margin of $41 \%$ to only $24 \%$ who disagreed), and spend too much time bickering with each other (76\%: 9\%).

The survey results clearly indicate that the main political parties are perceived to make no more than marginal advances towards young people — and the trend toward more media-centred and less interactive political campaigning is leaving today's youth generation feeling cut-off from politics. By a large majority (59\%:12\%), respondents agreed that those elected to parliament soon lose touch with people. Half of all young people that were questioned (50\%) claimed that in elections, political parties don't tell people about the really important problems facing the 
country, with only a fifth (21\%) dissenting from this view. Moreover, a large majority of attainers $(59 \%)$ considered that parties are not interested in the same issues that concern young people (only $10 \%$ disagreed). Very few young people had been contacted by the political parties during the 2001 General Election-90\% stated that they had received no telephone calls from any of the election candidates, and $70 \%$ had not been canvassed at home. Respondents noted that on the few occasions where the parties had been proactive in trying to engage young people, they had in the eyes of attainers proved incapable of effectively connecting with them: nearly half (44 per cent) agreed that "It's embarrassing when the parties try to appeal to young people during election campaigns" (only 26\% disagreed with this statement).

\section{Re-Connecting Young People: The Challenge for Political Parties}

Paradoxically, young people place direct contact from the parties at the top of their list of actions that must be taken if their antipathy to these same political parties and professional politicians is to be reversed. While there has been much discussion within Government circles and the mass media about the lack of engagement that young people have with politics, there is little evidence of systematic research into how young people can be re-connected to the political process. In an open question, the participants in this study were asked: 'What do you think the political parties could do to make better contact with young people?'. Their responses signalled very clearly that the main challenge was for the parties to reach out to young people in a direct, meaningful and non-patronising way. The responses are typified in the following answers:

- I believe they should INFORM young people about what's going on. I think a lot of people like me have absolutely no idea about what's going on. The parties should talk to us and explain what they believe is right. Us teenagers don't bite! 
- Encourage us to talk to them and engage with them uncynically

- Stop pretending they care about us and genuinely care. Rather than being fake with us, they could genuinely regard our opinions as important as middle class 40 year olds

- I detest cheap stunts - like wearing baseball caps or being an Oasis fan - but simply believe members of political parties should meet young people and listen to and take on board their views and concerns

- They should listen, visit schools, and they should respond to the opinions and views of the young people. There is no point in them making contact with young people if it's just for show and they're not going to do something about young peoples views

- It would be nice if they genuinely wanted to know what we think instead of giving token gestures and talking down to us

- Treat them [young people] more like adults. They try to appeal to young people by patronising them, that is not going to win votes!

By categorising these open responses thematically and conducting a quantitative analysis of the data, we found that over six in ten attainers consider that the political parties should do more to connect with young people, by making direct contact (26\%), listening to young people (21\%), and providing clearer information about their programmes and policy positions (10\%) - and in a less mystifying and more engaging manner (5\%). Buckingham has written of the difficulties in assessing young people's concerns about the conduct of political parties and politicians, and claims that "[e]xpressions of distrust in politicians have become almost ritualistic conversational clichés... reflect[ing] little more than a superficial form of cynicism" (2000, P.70). Yet he maintains that this derives less from any political apathy, and more from their sense of individual powerlessness and alienation. In many respects, the findings from our data reflect this assertion; 
18

the young people from our sample consider that there are few channels open for them to engage with politicians who are perceived to operate remotely and to persistently fail to actively and meaningfully connect with youth. If this current generation is to be brought back into the democratic fold, then political parties will need to reflect seriously on how they approach them in the future, as young people_rightly or wrongly_feel themselves to have been neglected and marginalised by politicians.

\section{Figure 3: The Challenge for Political Parties}

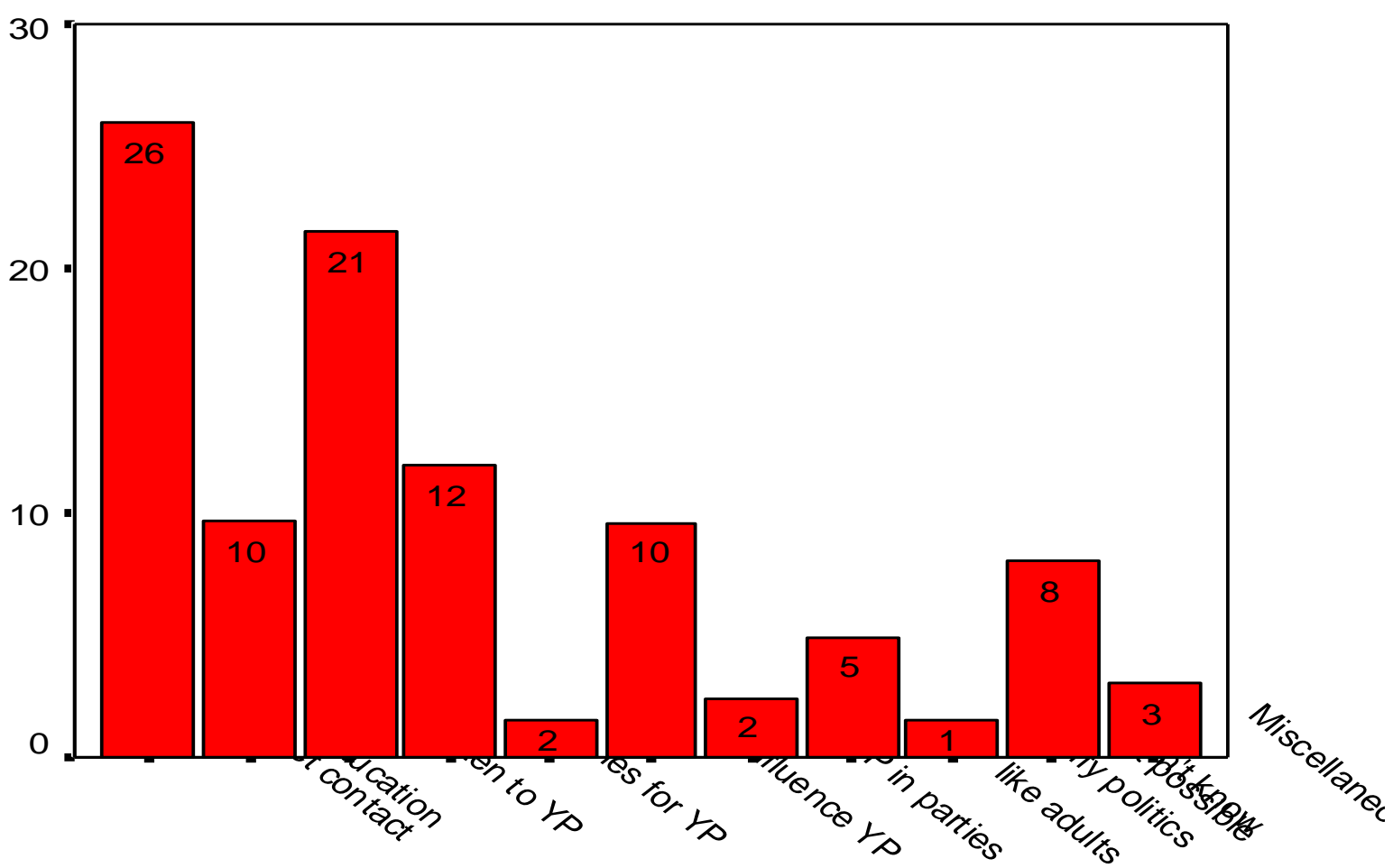

\section{Conclusion}

In this article, we have examined young people's orientation to 'politics' in Britain with a view to developing an understanding of their continuing disconnection from British politics, and their increasing tendency toward electoral abstention. The purpose in doing so has been to proffer an 
insight into whether or not Government initiatives aimed at engaging young people and encouraging them to vote in elections will have the intended effect. It was our contention at the outset that these initiatives by themselves would be unable to resolve these matters, because ongoing voting abstention is symptomatic of a generalised feeling of political alienation among the nation's youth generation and of their persisting disenchantment with the political system.

The evidence from our survey would appear to support this contention. The results indicate that young people's apparent reluctance to vote in elections does not signal a lack of interest in 'politics', nor does it indicate political apathy; the evidence presented here suggests that young people are concerned about political matters, and that they have a broad agenda of issueconcerns. Furthermore, young people are generally predisposed to the democratic process. They have a strong civic-orientation and a firm belief in the principles of voting and elections. However, there is an apparent inconsistency here in that this broad commitment to the democratic process is not translated into actual democratic participation. This paradox is compounded in that young people claim to have a very clear interest in the new balloting procedures currently under consideration (and in some cases, recently implemented) by the Government.

The answer to this empirical conundrum lies in an understanding of young people's perception of those who dominate the formal political realm - the political parties and professional politicians. The survey results indicate that while they have an interest in politics and a positive disposition towards the key tenets of representative democracy, young people have a deep antipathy to, and are roundly sceptical of, the political agents who dominate the political process. Thus, political parties and politicians are perceived to comprise a political class that is cynical, motivated 
primarily by partisan- and self-interests, and operating at a distance from, and therefore unappreciative of, the lived experiences of young people (and others) like themselves. It is this very remoteness that adds to a sense that young people feel ignored and lacking both political efficacy and any meaningful opportunities to influence those charged with governing on their behalf. If young people are to be re-connected to the political and democratic processes-and as part of this to be persuaded to vote in elections - then they need to feel confident that the political arena is an inclusive one, and that there are candidates worthy of their support and vote. The alienation that they currently claim to experience has roots that are deep and difficult to deracinate. Our findings indicate that young people would certainly welcome any efforts made by politicians and the political parties to actively engage with the public directly and on an on-going basis. Perhaps of more importance however, is that young people need to feel that political participation is a meaningful activity. At present they consider that the political world is a rather sterile one, inhabited by politicians offering very little by way of policies and priorities that are different from their rivals, or which have relevance for young people. Until such a time as young people consider that the political world is more inclusive and meaningful to them, they will continue to feel politically alienated, with relatively few incentives to vote. If this state of affairs were to continue, then the political system in Britain faces a crisis of democratic legitimacy.

\section{Acknowledgements}

This research was supported by the Economic and Social Research Council, award R000223598: First-Time Voters' Attitudes towards Party Politics in Britain. We would like to thank the ESRC for this support. We would also like to express our thanks to Rob Vickers and Neil Conant at Nottingham Trent University, both for their preparation of the data and for their general contribution to the project. 


\section{References}

BBC Online (2003) Turnout “Disappointing” says Raynsford, http://news.bbc.co.uk/1/hi/uk_politics/2995295.stm (Accessed 30 March 2006)

BBC Online (2004) 'Polls see boost in voter turnout' http://news.bbc.co.uk/1/hi/uk_politics/3796571.stm (Accessed 30 March 2006)

Bhavnani, K. (1994) Talking politics: A psychological framing of views from youth in Britain, Cambridge: Cambridge University Press.

Black, I. (2004) 'Apathy is greatest enemy' in Brussels Poll', Guardian Unlimited, http://politics.guardian.co.uk/elections2004/story/0,14549,1235272,00.html (Accessed 30 March 2006)

Bryman, A. (2001) Social research methods, Oxford: Oxford University Press.

Buckingham, D. (2000) The making of citizens: Young people, news and politics, London: Routledge.

Bynner, J. and Ashford, S. (1994) 'Politics and participation: Some antecedents of young people's attitudes to the political system and political activity', European Journal of Social Psychology, vol 24: 223-236.

Cole, M. (1997) 'Politics and youth', Politics Review, 5-9.

Crace, J. (2000) 'The new citizens', Guardian Unlimited, http://education.guardian.co.uk/old/schools/story/0,10044,136694,00.html, (Accessed 30 March 2006).

Crick, B. (1998) Education for citizenship and the teaching of democracy in schools: Final report of the Advisory Group on Citizenship, (London).

Cunningham, S. and Lavallette, M. (2004) “"Active citizens” or "Irresponsible truants”? School student strikes against the War', Critical Social Policy, vol 24, no 2: 255-69. 
Curtice, J. (2002) 'Is there a general pattern of decline?', Turnout in the 2001 and 2002 elections: What can be done to reverse the general decline? And by whom? Paper presented to the Conference of The Electoral Commission and The Constitution Unit, London, 18 June 2002.

Dennis, J., Lindberg, L. and McCrone, D. (1971) 'Support for Nation and government among English schoolchildren', British Journal of Political Science, vol 1: 21-44.

Department of the Environment, Transport and the Regions (1998) Modernising local government: In touch with the people, White Paper. London: HMSO.

Electoral Commission (2004) Delivering democracy? The future of postal voting, London: The Electoral Commission.

Electoral Commission (2005a) Election 2005: Turnout, how many, who and why?. London: The Electoral Commission.

Electoral Commission (2005b) Securing the vote: Report and recommendations. London: The Electoral Commission.

Guardian Unlimited (2004) "EU vote turnout a "Wake up call", http://politics.guardian.co.uk/elections2004/story/0,14549,1238704,00.html, （Accessed 30 March 2006)

Harrop, M. (2001) 'An apathetic landslide: The British general election of 2001', Government and Opposition, vol 36:295-313.

Hart, V. (1978) Distrust and democracy, Cambridge: Cambridge University Press.

Heath, A. and Park, A. (1997) 'Thatcher's children?', in R. Jowell et al., (eds.) British social attitudes: The 14th Report. The end of Conservative values?, Aldershot: Ashgate.

Henn, M., Weinstein, M., and Wring, D. (2002) 'A generation apart? Youth and political participation in Britain', British Journal of Politics and International Relations, vol 4, no 2: $167-192$. 
Henn, M. (1998) Opinion polls and volatile electorates: Problems and issues in polling European societies, Aldershot: Ashgate.

Hetherington, P. (2004) 'Scrap all-postal voting, says watchdog', The Guardian [Online]. Available at: http://www.guardian.co.uk/print/0,3858,5002943-103685,00.html (Accessed 30 March 2006).

Jennings, I. (1960) Party politics: Appeal to the people, Cambridge: Cambridge University Press.

Johnson, C. and Marshall, B. (2004) Political engagement among young people: An update, London: The Electoral Commission.

Johnston, P. (2001) 'Low poll takes shine off win', Telegraph.Co.Uk, http://www.telegraph.co.uk/news/main.jhtml?xml=\%2Fnews\%2F2001\%2F06\%2F09\%2Fnpoll 09.xml, (Accessed 30 March 2006).

Jowell, R. and Park, A. (1998) Young people, politics and citizenship: A disengaged generation?, London: Citizenship Foundation.

Layton-Henry, Z. (1973) Political youth organisations in Britain: A comparative study of the young (Unpublished $\mathrm{PhD}$, Birmingham University).

Marsh, A. (1977) Protest and political consciousness, London: Sage.

Meguid, B. (2003) Bringing government back to the people? The impact of political decentralisation on voter engagement in Western Europe. Paper presented to the European Consortium for Political Research Joint Sessions, Edinburgh University, $28^{\text {th }}$ March $-2^{\text {nd }}$ April.

Mulholland, H. (2004) 'North-East voters reject regional assembly', The Guardian [Online]. Available at: http://www.guardian.co.uk/print/0,3858,5055633-103690,00.html (Accessed 30 March 2006). 
Mulgan, G. and Wilkinson, H. (1997) 'Freedom's children and the rise of generational politics', in G. Mulgan (ed.) Life after politics: New thinking for the twenty-first century. London: Fontana Press.

Norris, P. (2003) 'Young people and political activism: From the politics of loyalties to the politics of choice?', Paper presented to the Council of Europe Symposium, Young people and democratic institutions: From disillusionment to participation, Strasbourg, 27 - 28 November 2003.

O’Toole, T., Lister, M., Marsh, D., Jones, S., and McDonagh, A. (2003) 'Tuning out or left out? Participation and non-participation among young people', Contemporary Politics, vol 9, no $1: 45-61$.

Park, A. (2000) 'Young people and political apathy', in R. Jowell et al. (eds.) British social attitudes: The 16th report. Who shares New Labour values?, Aldershot: Ashgate.

Parry, G., Moyser, G., and Day, N. (1992) Political participation and democracy in Britain, Cambridge: Cambridge University Press.

Pirie, M. and Worcester, R. (1998) The millennial generation, London: Adam Smith Institute.

Pirie, M. and Worcester, R. (2000) The big turn-off: Attitudes of young people to government, citizenship and community, London: Adam Smith Institute.

Preston, P. (2004) 'Stop your whining and start voting', The Guardian, 29 March: 17.

Roker, D. and Eden, K. (2002) '...Doing something': Young people as social actors, Leicester: National Youth Agency.

The Royal Commission on the Constitution (1973a) Vol. 1, Report, Cmnd. 5460. London: HMSO.

The Royal Commission on the Constitution (1973b) Vol. 2, Memorandum of dissent, Cmnd. 5460. London: HMSO. 
Russell, A., Fieldhouse, E., Purdam, K., and Kalra, V. (2002) Voter engagement and young people, London: The Electoral Commission.

Swaddle, K., and Heath, A. (1989)' Official and reported turnout in the British general election of 1987', British Journal of Political Science, vol 19:537-550.

Weinstein, M., (2004) 'Political activity and youth in Britain', in G. Taylor and M. Todd, (eds.) Democracy and protest: New social movements in liberal democracies, London: Merlin Press.

White, C., Bruce, S. and Ritchie, J. (2000) Young people's politics: Political interest and engagement amongst 14- to 24- year-olds, York: York Publishing Services.

Whiteley, P., Clarke, H., Sanders, D. and Stewart, M (2001) 'Turnout', in P. Norris (ed.) Britain votes 2001, Oxford: Oxford University Press.

Wilkinson, H. (1996) 'But will they vote? The political attitudes of young people'. Children and Society, vol.10, no.3:242-4.

\section{Notes}

${ }^{1}$ A record low of only 30 per cent voted at the May 1998 local elections whilst the 1999 Leeds Central by-election recorded the lowest peacetime turnout rate at 19.5 per cent.

${ }^{2}$ See also Russell et al. (2002).

${ }^{3}$ Whether or not citizens consider that these reforms provide them with enhanced opportunities to participate in, and acquire influence over, the political process is debateable. Following reform of the electoral system, turnout at the 1999 European Assembly elections in Britain actually fell to 23 per cent from 36 per cent in 1994 , before increasing to only 39 per cent in 2004 . Less than half of the eligible electorate voted in the 2004 referendum on the establishment of a regional assembly for the North East of England, with 77.9\% voting 'No'. Reflecting on the implications of this result, John Tomeney, chairman of the Yes 4 The North East campaign, suggested that this 
signalled "a growing breakdown in the belief that political institutions can affect people's lives for the better. This should concern us all" (Mulholland, 2004). Furthermore, voter turnout at the 1999 and 2003 Welsh Assembly and Scottish Parliamentary contests has actually declined over the period, from 46 per cent to 38 per cent in Wales, and from 59 per cent to 49 per cent in Scotland. This is perhaps not surprising. Meguid (2003) claims for instance that political engagement and participation in elections is likely to increase amongst supporters of prodevolution parties, and fall amongst supporters of anti-devolution parties. In combination, this evidence would seem to indicate that the introduction of new democratic structures and procedures are by themselves failing to meaningfully reverse the continuing disconnection between citizens and the political system.

${ }^{4}$ For instance, at the Local Authority elections held in May 2003, all-postal voting increased turnout by an average of 13 per cent in the thirty two areas in which it was introduced, whilst in the seventeen areas where telephone and electronic voting had been employed, the impact was negligible except in only two or three cases (BBC Online, 2003). At the 2004 Local Authority elections, overall voter turnout did increase from 31 to 40 per cent-marginally more in those four regions that used all-postal voting (by 13 per cent) than in areas that used the traditional polling station method (an increase of 7 per cent) (BBC Online, 2004). The introduction of allpostal voting was met with much criticism in the media which may have undermined public confidence in the method. In part, national media attention highlighted the operational shortcomings and logistical problems encountered in certain regions (particularly the North West) of mailing local electorates the ballot papers in time for the election contests. This was also of major concern to the Electoral Commission (2004) in its report of August 2004. Furthermore, serious allegations of fraud were levelled at local parties and candidates in areas such as (Birmingham, Greater Manchester, and Lancashire) which may have served to heighten the public's scepticism of the election process and therefore had some cost to political legitimacy in 
Britain (Hetherington, 2004). At the 2005 General Election, more than 5 million people - some $15.5 \%$ of the electorate - opted to vote by post rather than attend the polling stations in person. Nonetheless, overall turnout increased by only 2 per cent from the record low witnessed at the previous contest in 2001, and the integrity of the system was called into question following various allegations of fraud as well as problematic experiences in the organisation of the method (The Electoral Commission, 2005b).

5 Thus, the Local Government Minister, Nick Raynsford claimed that the new voting methods initiated at the 2003 local elections represented the future of elections in Britain: "It shows that these innovative arrangements to make possible new ways of voting can make a real difference" (BBC Online, 2003).

${ }^{6}$ For instance, Bryman states that such questions require more effort, attention and concentration to complete than do closed "tick-box" questions, and may put off many respondents. Indeed, he claims that the inclusion of such open questions "exacerbate the problem of low response rates with mail questionnaires in particular" (Bryman 2001, p.143). Given this, the level of detail reported in their answers and the serious way in which these questions were completed would seem to suggest that the young respondents in our survey were motivated to demonstrate their interest in political issues.

${ }^{7}$ This data tells us more about respondents' general attitudes to elections than it does about their actual likely voting behaviour, and evidence suggests that respondents often over-estimate their likelihood to vote in elections when asked in surveys (see Swaddle and Heath, 1989; Henn, 1998).

${ }^{8}$ Turnout amongst the 18-24 age group declined from $68 \%$ at the 1997 General Election to only $39 \%$ at the corresponding election in 2001. 
${ }^{9}$ What is equally interesting is that for all proposals there are almost as many young people reporting that the new methods would make no difference to their likelihood to vote than would make a positive impact. In the case of proposals for 24 hour voting, and voting in public places, the ambivalent were dominant. 